\title{
Evaluation of Walking Behind Harvester for Wheat Crop
}

\author{
Ashebir Tsegaye ${ }^{1}$ and Abulasan Qabaradin ${ }^{2}$ \\ Oromia Agricultural Research Institute, Asella Agricultural Engineering Research Center \\ P.O. Box 06 Assela Ethiopia
}

\begin{abstract}
The walking behind harvester (TNS Model 4S-120 imported) was evaluated for its performance by harvesting of wheat crops. The field evaluation was carried out at Kulumsa Agricultural Research Center experimental site. Parameters and measurements considered during this study were crop parameters, operating parameters of the harvesting machine, harvesting losses and cost of harvesting. The average effective field capacity and field efficiency of the harvester was found to be $0.182 \mathrm{ha} / \mathrm{h}$ and $81 \%$ respectively whereas the effective field capacity in manual harvesting was $0.008 \mathrm{ha} / \mathrm{h}$. Fuel consumption of the reaper was $0.92 \mathrm{lit} / \mathrm{h}, 5.08 \mathrm{lit} / \mathrm{ha}$. Average value of harvest losses in mechanical harvesting was 1.42 percent only whereas average value of harvesting losses in manual harvesting was $1.73 \%$ which is more than that of mechanical harvesting. The cost of harvesting for harvester and for manual harvesting were 479Birr/ha and 1600Birr/ha respectively. The percent saving in the cost of harvesting is reduced by $30 \%$ harvesting of wheat with harvester over manual harvesting. Hence, the machine harvesting would be feasible and economical compared to manual harvesting method in terms of time, money and labor requirement.
\end{abstract}

Keywords: walking behind harvester, field capacity, field efficiency, harvesting lose.

DOI: $10.7176 /$ ISDE/12-2-01

Publication date: April $30^{\text {th }} 2021$

\section{INTRODUCTION}

Ethiopia is an agrarian economy with a mainly rain fed agricultural system, where wheat (Triticumvulgare) and barley are among the main cereal crops which contribute about $68.3 \%$ of the national food grain production (CSA, 2008). Ethiopia is the second largest wheat producing country in Africa followed to South Africa. Wheat is mainly grown in the central and south eastern highlands during the main (Meher) rainy season (June to September) and harvested in October-November. Arsi, Bale, and parts of Shoa are considered the wheat growing belt.

Harvesting is one of the most important operations of farming activities. Most of the parts of the country have been harvesting manually. This is a labour intensive seasonal operation consuming about $18-20 \%$ of the Labour required for growing cereal crops (Singh et al., 2008). The traditional method of harvesting with sickle is both labour as well as time consuming, where both are scarce during the peak harvesting season. Labour scarcity during peak period of harvesting leads to delay in harvesting and field grain losses. Also high labour cost during peak period adds extra cost in total cost of harvesting.

Mechanized harvesting is an alternative solution to tackle this problem. As a step towards mechanization of the harvesting operation for cereal crops, the alternatives available were considered such as self-propelled combine harvesters and tractor mounted combine harvesters. The uses of combine harvesters have their limitations. The farmers want to recover both grains as well as the straw from wheat crops, because the straw is main source of feeds of the cattle. Moreover, Ethiopian farmers' fragmented and small farm size holdings, over 69 percent of smallholder farmers in the cereal growing own farmlands less than or equal to one hectare (CSA, 2013). However, high level harvesting combine harvester is not affordable for them.

Most of the cereal crops are harvested by sickle which is quite tedious and labour-intensive job. During the peak season of harvesting, farmers face the difficulty of getting their crop timely reaped due to shortage of agricultural labourers. Non-availability of labor due to increased rural-urban migration. Hence, keeping these facts in view, this study was conducted to evaluate the performance of the walking behind harvester machine and introduce technology options, to minimize the cost of harvesting through farm mechanization.

\section{MATERIAL AND METHODS}

The experiment was conducted at Kulumsa Agricultural Research Center (KARC) research farm near the city of Asella in 2015/16 cropping season. Wheat harvesting was performed manually with sickle and with mechanical harvester. The detailed manufacturers technical specifications of walking behind harvester used for field performance evaluation used are presented below in table 1:- 
Table 1. Technical specification of vertical conveyor walking behind reaper

\begin{tabular}{|l|l|l|}
\hline No. & Parameters & Specifications \\
\hline 1 & Manufacturers & ZHEJING TING SHENG MACHINE CO. LTD. \\
\hline 3 & Model & TNS-4S-120 \\
\hline 4 & Dimensions $(\mathrm{L} \mathrm{x} \mathrm{W} \mathrm{x} \mathrm{H)} \mathrm{cm}$ & $239 \times 147 \times 90$ \\
\hline 5 & Weight $(\mathrm{kg})$ & 165 \\
\hline 6 & Power unit & $\begin{array}{l}5.5 \mathrm{HP} \text { single cylinder } 4 \text { stroke, air cooled, petrol start, kerosene run } \\
\text { engine }\end{array}$ \\
\hline 7 & Working capacity (ha/hr) & 0.25 \\
\hline 8 & Crop release & Right side of the machine (viewed from rear) \\
\hline 9 & Operating speed $(\mathrm{km} / \mathrm{hr})$ & 2 \\
\hline 10 & Applicability & Dry land \\
\hline 11 & Cutting device & Reciprocating cutter bar \\
\hline 12 & Cutting height $(\mathrm{cm})$ & $10-30$ from ground level \\
\hline 13 & Cutting width $(\mathrm{cm})$ & 120 \\
\hline
\end{tabular}

\section{Field Experiment}

Experimental plot size of $300 \mathrm{~m}^{2}$ was harvested by mechanical harvester and manual with sickle and replicated three times for each as shown in figure 1(experimental lay out). The area of the plot was measured with tape. Also randomly three small areas were selected in the plot for determining shattering loss. To calculate the operational speed of harvester, time was recorded that was taken to travel a certain distance. The distance was measured with a measuring tape and time was counted with a stop watch. Such operations were done in several times to calculate the average speed of operation. The actual field capacity was calculated by dividing the total area harvested by total time taken to harvest a certain plot. The theoretical field capacity was calculated by the formula.

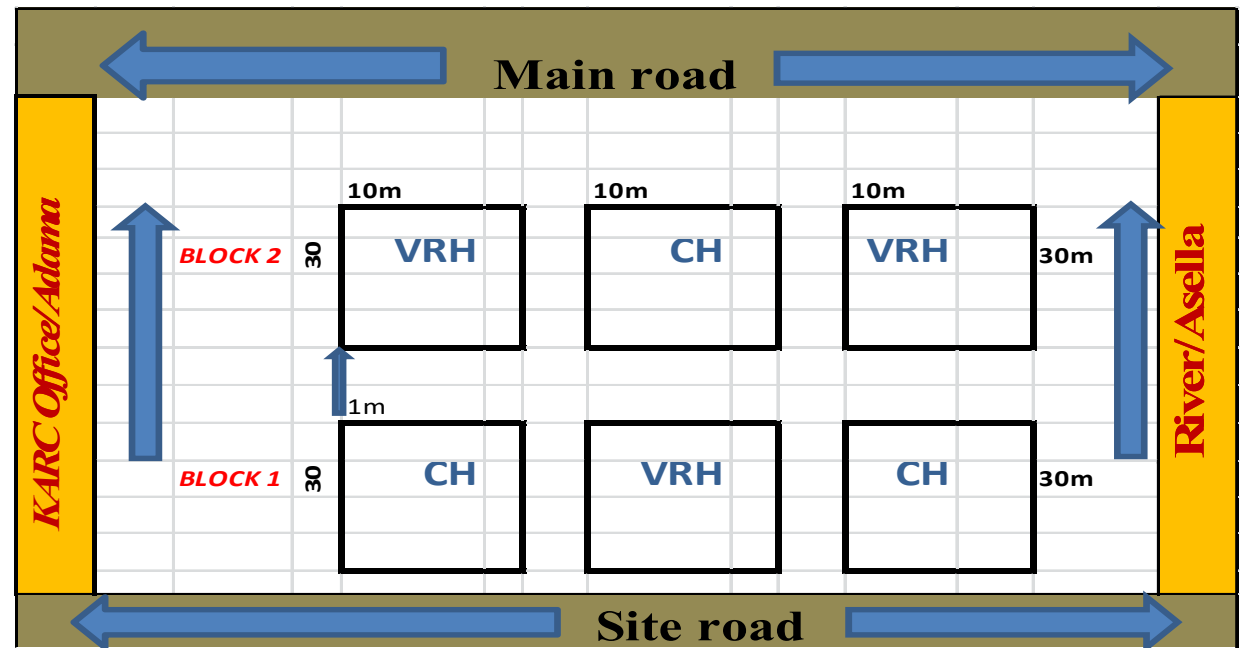

*-Figure 1 Experimental plot lay out of wheat fields

\section{Performance of the Machine}

\section{Harvesting Losses}

In order to estimate harvesting losses in manual and reaper harvesting, losses that occur before harvesting (preharvest) was collected and measured. Harvesting losses include shattering and uncut losses were determined by the following equation (Pradhan, 1998):-

$$
W_{g t}=w_{g 1}+w_{g 2}+w_{g 3}
$$

Where:- $\mathrm{W}_{\mathrm{gt}}=$ Total grain losses $\left(\mathrm{g} / \mathrm{m}^{2}\right), \mathrm{w}_{\mathrm{g} 1}=$ Pre-harvest grain loss $\left(\mathrm{g} / \mathrm{m}^{2}\right), \mathrm{w}_{\mathrm{g} 2}=$ Grain loss from uncut panicle $\left(\mathrm{g} / \mathrm{m}^{2}\right)$ and $\mathrm{w}_{\mathrm{g} 3}=$ Shattering grain loss (grain from cut panicle but fallen and grain loss on ground) $\left(\mathrm{g} / \mathrm{m}^{2}\right)$

After measuring the amount of losses at different stages, the percentage of harvesting loss was determined by the following equation (Pradhan, 1998):- 


$$
H_{L}=\frac{W_{g t}-w_{g 1}}{W_{g p y}} \times 100
$$

Where: $-\mathrm{H}_{\mathrm{L}}=$ Harvesting grain loss $(\%), \mathrm{Wg}_{1}=$ Pre-harvest grain loss $\left(\mathrm{g} / \mathrm{m}^{2}\right), \mathrm{W}_{\mathrm{gt}}=$ Total grain losses $\left(\mathrm{g} / \mathrm{m}^{2}\right)$ and $\mathrm{W}_{\mathrm{gPy}}=$ Potential yield $\left(\mathrm{g} / \mathrm{m}^{2}\right)$

\section{Conveying Loss}

In order to estimate conveying losses in manual and reaper harvesting five sets of sample were taken using a canvass spread of $2 \mathrm{~m}$ length on a place where cut stalks were fall. Detached grains from the panicle was collected and recorded. Percentage of conveying loss was determined by the following equation:-

$$
C_{L}=\frac{L_{C}}{W_{g p y}} \times 100
$$

Where: $\mathrm{C}_{\mathrm{L}}=$ Conveying loss $(\%), \mathrm{L}_{\mathrm{C}}=$ Average conveying loss $\left(\mathrm{g} / \mathrm{m}^{2}\right)$,

$$
\mathrm{W}_{\mathrm{gPy}}=\text { Potential yield }\left(\mathrm{g} / \mathrm{m}^{2}\right)
$$

\section{Total machine Loss}

After determining the amount of different harvesting losses of the machine, the percentage of total harvesting loss of the machine was determined by the following equation:-

$$
T_{L}=H_{L}+C_{L}
$$

Where: - $\mathrm{T}_{\mathrm{L}}=$ Total machine loss $(\%), \mathrm{H}_{\mathrm{L}}=$ Harvesting loss $(\%)$ and $\mathrm{C}_{\mathrm{L}}=$ Conveying loss, $\%$

\section{Machine Performance}

Forward speed of the machine was determined to compute the theoretical field capacity of the harvesting machine. Total operation time and lost time (turning time loss, operator personal time loss and machine adjustable time loss) during field operation was recorded to calculate the actual field capacity of the machine. The following formulas were used to compute theoretical field capacity, actual field capacity and field efficiency.

Theoretical field capacity was calculated based on the speed of operation and cutting width of the harvester as follows (R. Jaya Prakash et al, 2015):-

$$
F_{C T}=\frac{W_{C} \times S_{O}}{10}
$$

Where: $\quad \mathrm{F}_{\mathrm{CT}}=$ Theoretical field capacity $(\mathrm{ha} / \mathrm{h}) \mathrm{W}_{\mathrm{C}}=$ Cutting width $(\mathrm{m})$ and

$$
\text { So }=\text { Operating speed, } \mathrm{km} / \mathrm{h}
$$

Actual field capacity was computed based on area covered and actual time taken for covering the given area including the time lost during operation as follows:

$$
F_{C A}=\frac{A_{T}}{T_{t}}
$$

Where: $\mathrm{F}_{\mathrm{CA}}=$ Actual field capacity $(\mathrm{ha} / \mathrm{hr}), \mathrm{A}_{\mathrm{T}}=$ Area covered during test (ha),

$\mathrm{T}_{\mathrm{t}}=$ Total operating time, $\mathrm{hr}$

The field efficiency was obtained from the ratio of the actual field capacity to the theoretical field capacity of the machine and expressed in percent as follows:-

$$
E=\frac{F_{C A}}{F_{C T}} \times 100
$$

Where: $\quad \mathrm{E}=$ Field Efficiency $(\%), \mathrm{F}_{\mathrm{CA}}=$ Actual field capacity $(\mathrm{ha} / \mathrm{h})$, and $\mathrm{F}_{\mathrm{CT}}=$ Theoretical field capacity, ha/h

\section{Cost Analysis}

Harvesting cost of the harvester included cost of labor, machine depreciation, machine repair, fuel and lubricants. Labor cost included wages for the machine operator and the assistant operator. The harvesting cost for harvester is calculated on the basis of fixed and variable costs. The local purchase price of the reaper was 52,000birr. 


\section{Fixed Costs}

Fixed cost of the machine is the cost which is involved irrespective of whether the machine is used or not. These costs include; Depreciation cost, interest on investment and taxes, shelter and insurance. Depreciation cost was calculated by straight line method. Useful life of harvester considered to be 10 years. The salvage value was also considered to be $10 \%$ of purchase price.

The annual Depreciation, $\mathrm{D}=\frac{P-S}{L}$

Where, $\mathrm{P}=$ purchase price (Birr), $\mathrm{S}=$ selling price (Birr), $\mathrm{L}=$ Useful life, $\mathrm{yr}$.

Interest on Investment is an actual cost in agricultural machinery and was calculated by Straight Line Method.

Interest on Investment, $\mathrm{I}=\frac{P+S}{2} i$

Where, $\mathrm{P}=$ Purchase price, Birr. $\mathrm{S}=$ Resale value, Birr. $\mathrm{i}=$ annual interest rate

Shelter, Tax and Insurance cost of the machine were annually estimated as follows:-

Shelter, Tax and Insurance, $\mathrm{STI}=2.5 \% \mathrm{p}$

Total Fixed Cost $\left(\frac{\mathrm{Birr}}{\mathrm{Yr}}\right)=D+I+\mathrm{STI}$

Fixed Cost $\left(\frac{\text { Birr }}{\text { ha }}\right)=\frac{\text { Total Fixed Cost }\left(\frac{\text { Birr }}{\mathrm{Yr}}\right)}{\text { Total Area Coverage }\left(\frac{\mathrm{ha}}{\mathrm{Yr}}\right)}$

\section{Variable Costs}

Fuel, oil, labor, repair and maintenance cost were considered as variable costs of the machine and determined by the following formulas:

Fuel Cost $\left(\frac{\text { Birr }}{\text { ha }}\right)=\frac{\text { Fuel consumed }\left(\frac{\text { Litre }}{\text { Day }}\right) \times \text { Price }\left(\frac{\text { Birr }}{\text { Litre }}\right)}{\text { Area Coverage }\left(\frac{\text { ha }}{\text { Day }}\right)}$

Oil Cost, $O\left(\frac{\text { Birr }}{\text { ha }}\right)=15 \%$ of fuel cost, $F$

Loubor Cost, $L\left(\frac{\text { Birr }}{\text { ha }}\right)=\frac{\text { Some of wages of loubors }\left(\frac{\text { Birr }}{\text { Day }}\right)}{\text { Area Coverage }\left(\frac{\text { ha }}{\text { Day }}\right)}$

Repaire and Maintenanc, $\mathrm{R} \& \mathrm{M}\left(\frac{\mathrm{Birr}}{\mathrm{Yr}}\right)=3.5 \%$ of purchase price, $\mathrm{P}$

Total Variable Cost $\left(\frac{\text { Birr }}{\text { ha }}\right)=(\mathrm{F}+\mathrm{O}+\mathrm{L}+\mathrm{R} \& \mathrm{M}) \frac{\text { Birr }}{h a}$

Total cost of Harvesting $\left(\frac{\text { Birr }}{\text { Yr }}\right)=$ Fixed cost $\left(\frac{\text { Birr }}{\text { ha }}\right)+$ Variable cost $\left(\frac{\text { Birr }}{\text { ha }}\right)$

\section{Break-Even Point}

The break-even point is that area in which the harvesting cost per unit area is equal for machine and manual, 
determined by the following equation described by Alizadeh et al., (2013).

$$
\text { Break - even point, } \mathrm{B}=\frac{F}{V_{a}-V_{m}}
$$

Where, $\mathrm{B}=$ Break - even point (ha/year), $\mathrm{F}=$ Fixed costs of Machine (Birr/year)

$\mathrm{V}_{\mathrm{a}}=$ Variable costs for manual method (Birr/ha)

$\mathrm{V}_{\mathrm{m}}=$ Variable costs for machinery method (Birr/ha)

\section{RESULT AND DISCUSSION}

The walking behind harvester was evaluated for its performance by harvesting of wheat during 2015/16 harvesting season. The experiments were carried out in the extent of 0.18 ha at Kulumsa Agricultural Research Center of research farm. Parameters and measurements considered during this study were crop parameters, machine performance parameter, harvesting losses and cost of operations. The results of field performance based on test conducted are summarized in Table 2 and 3.

Table 2. Details of crop parameters

\section{Particulate}

\section{Crop}

Height of plant, $\mathrm{cm}$

Number of tillers per sq. $m$

Height of cut, cm

Condition of crop

Grain moisture content, \%

Straw moisture content, $\%$

\begin{tabular}{lllll}
\multicolumn{5}{c}{ Harvesting Methods } \\
\cline { 1 - 3 } & \multicolumn{3}{c}{ Mechanical harvester } & Manual harvesting \\
\cline { 1 - 3 } & Trial & Mean value & \\
97.2 & Wheat & & Wheat \\
252 & 24.6 & 87.9 & 91.6 & 90.2 \\
20 & 13 & 287 & 261 & 261 \\
erect & erect & erect & - & 32 \\
8.9 & 8.6 & 8.7 & 8.73 & erect \\
8.32 & 8.47 & 8.47 & 8.42 & 8.73 \\
& & & & 8.42 \\
\hline
\end{tabular}

Table 3: Test results of mechanical harvester compared with manual harvesting by sickle

\begin{tabular}{|c|c|c|c|c|c|}
\hline \multirow{4}{*}{ Parameter } & \multicolumn{4}{|c|}{ Harvesting Methods } & \multirow{4}{*}{$\begin{array}{c}\text { Manual } \\
\text { harvesting }\end{array}$} \\
\hline & \multicolumn{4}{|c|}{ Mechanical harvester } & \\
\hline & \multicolumn{4}{|c|}{ Trial } & \\
\hline & 1 & 2 & 3 & Average & \\
\hline Actual area covered (ha) & 0.03 & 0.03 & 0.03 & 0.03 & 0.03 \\
\hline No. of Labours & 1 & 1 & 1 & 1 & 5 \\
\hline Total time of operation (min) & 10.25 & 9.45 & 10 & 9.73 & 44.40 \\
\hline Effective working width (cm) & 120 & 120 & 120 & - & - \\
\hline Forward speed (km/h) & 1.95 & 1.78 & 1.88 & 1.87 & - \\
\hline Theoretical field capacity (ha/hr) & 0.234 & 0.214 & 0.226 & 0.225 & - \\
\hline Actual Field capacity (ha/hr) & 0.175 & 0.190 & 0.180 & 0.182 & 0.008 \\
\hline Field efficiency $\%$ & 74.78 & 88.78 & 79.64 & 81 & - \\
\hline Labour requirement, man-hr/ha & 5.69 & 5.25 & 5.56 & 5.5 & 123.33 \\
\hline Fuel consumption (lit/hr) & 1.06 & 0.79 & 0.92 & 0.92 & - \\
\hline Fuel consumption (lit/ha) & 5.83 & 4.33 & 5.08 & 5.08 & - \\
\hline Potential grain Yield $\left(\mathrm{gm} / \mathrm{m}^{2}\right)$ & 533.95 & 482.87 & 606.18. & 541 & 541 \\
\hline Harvesting losses (g/m2) & 5.85 & 7.50 & 6.60 & 6.65 & 7.99 \\
\hline Harvest losses (shattering + Uncut) $\%$ & 1.10 & 1.55 & 1.08 & 1.22 & 1.48 \\
\hline Conveying loss (g/m2) & 1.10 & 1.19 & 1.04 & 1.11 & 1.37 \\
\hline Conveying loss, $\%$ & 0.20 & 0.24 & 0.17 & 0.20 & 0.25 \\
\hline Total harvesting loss, $\%$ & 1.30 & 1.79 & 1.25 & 1.42 & 1.73 \\
\hline
\end{tabular}

\section{Machine Performance}

Measurements of harvester performance for wheat crop were the rate and quality of the machine at which the operations are accomplished. The mean value of the performance parameter that include time losses; total working time, test plot area, cutting width, cutting height, operating speed, theoretical field capacity, actual field capacity and field efficiency are shown in Table 3. The cutting width was 1.2 meter and the operating forward speed of the machine was found $1.87 \mathrm{~km} / \mathrm{h}$. The actual field capacity of the reaper for wheat crop was $0.182 \mathrm{ha} / \mathrm{h}$. The theoretical field capacity of the machine is a function of speed of travel and cutting width and computed result is $0.225 \mathrm{ha} / \mathrm{h}$. Field efficiency of reaper harvesting machine was $81 \%$. In manual harvesting with sickle, a laborer on average can harvest $80 \mathrm{~m}^{2} / \mathrm{hr}$, but this amount can differ with respect to crop condition, laborer ability 
and weather condition. The required time for harvesting one hectare of wheat in manual harvesting was 123.33 man-h/ha compared to $5.5 \mathrm{man}-\mathrm{h} / \mathrm{ha}$ for the harvesting (Table 3). The harvester was 22.42 times faster compared to manual harvesting.

\section{Harvesting Losses}

The measured values of harvesting, conveying losses and total harvesting (conveying and harvesting) losses for wheat in reaper and manual harvesting methods are presented in Table 2. The mean percentage of conveying losses in reaper and manual harvesting for wheat crop were $0.20 \%$ and $0.25 \%$ respectively and that of harvesting losses were $1.22 \%$ and $1.48 \%$ respectively. The total losses in reaper and manual harvesting were $1.42 \%$ and $1.73 \%$. In earlier study, S.S. Karahle (2015) reported that $0.93 \%$ harvesting loss during harvesting of wheat by self-propelled reaper binder against $1.83 \%$ loss of manual harvesting.

\section{Economic Analysis}

The local purchase price of the reaper was 52,000birr. The annual fixed cost (7410 Birr) and variable cost (68.34Birr/h) were found from the calculation. The working hour of the reaper was considered 416 hours per year. The fixed cost and variable costs for both reaper and manual harvesting are presented in Table 3 . In this study, manual harvesting required 16 man-days to harvest one hectare of wheat field. Considering the labor cost as 100Birr per day, $1600 \mathrm{Birr} /$ ha was required for manual harvesting, whereas $479.01 \mathrm{Birr} / \mathrm{ha}$ was calculated for reaper harvesting (Table 3).

Net savings per hectare area as shown in Table 4, indicate that 1,251.91 Birr/ha could be saved as compared reaper harvesting against manual harvesting. This net saving comes because of higher field capacity of reaper than manual harvesting field capacity. In a previous study, net savings (1770 Bhat/ha) was found by Bora and Hansen (2007) who harvested rice by a reaper (40 Bhat $=1$ US\$).

Table 3: Harvesting cost of reaper and manual harvesting

\begin{tabular}{|c|c|c|c|c|c|}
\hline \multicolumn{4}{|l|}{ Machine harvesting cost } & \multicolumn{2}{|c|}{ Manual harvesting cost } \\
\hline Cost items & Birr/Year & Birr/ha & Birr/hr & Birr/ha & Birr/hr \\
\hline \multicolumn{4}{|l|}{ Fixed cost } & \multirow{11}{*}{1600} & \multirow{11}{*}{12.50} \\
\hline Depreciation & 4,680 & 62.55 & 11.25 & & \\
\hline Interest & 1,430 & 19.13 & 3.44 & & \\
\hline Taxes, insurances and shelter Total fixed & 1,300 & 17.40 & 3.13 & & \\
\hline cost & 7,410 & 99.08 & 17.82 & & \\
\hline \multicolumn{4}{|l|}{ Variable cost } & & \\
\hline Fuel & $14,094.08$ & 188.35 & 33.88 & & \\
\hline lubrication & $2,114.11$ & 28.25 & 5.08 & & \\
\hline labor & 10,400 & 139 & 25 & & \\
\hline Repair and maintenance & 1,820 & 24.33 & 4.38 & & \\
\hline Total variable cost & $28,428.19$ & 379.93 & 68.34 & & \\
\hline Total cost of harvesting & $35,838.19$ & 479.01 & 86.16 & 1600 & 12.5 \\
\hline
\end{tabular}

Table 4: Comparison of savings by the reaper harvesting per hectare

\begin{tabular}{llll}
\hline Particulars & Calculation & Amount (Birr) \\
\cline { 1 - 1 } Cost of manual harvesting (16 man-days/ha) & $16 \times 100$ & 1600 \\
Cost of machine harvesting/ha & 479.01 & 479.01 \\
Gross savings & $1600-479.01$ & $1,120.99$ \\
Cost of total output $(5400 \mathrm{~kg} / \mathrm{ha} @ 8 \mathrm{birr} / \mathrm{kg})^{*}$ & $8 \times 5400$ & 43,200 \\
Loss in reaper harvesting, $(1.42 \%)$ & $43,200 \times 0.0142$ & 613.44 \\
Loss in manual harvesting $(1.73 \%)$ & $43,200 \times 0.0173$ & 747.36 \\
Excess loss due to manual harvesting & $747.36-613.44$ & 133.92 \\
The net savings per hectare & $1,120.99+133.92$ & $1,251.91$ \\
\hline
\end{tabular}

*Considered the production of wheat 54 quintal per hectare

\section{Break-even Point Analysis}

Harvesting cost by a reaper is found to be decreased gradually with the increase of harvesting area. However, break-even point is 6 ha of land where same cost will be found for both of reaper and manual harvesting. This break-even point indicates that reaper would be beneficial to the farmers when the area of the harvesting land is more than 6 hectare of land per year. 


\section{SUMMERY AND CONCLUSIONS}

Based on the field performance evaluation harvester conducted during harvesting season of 2016/17, it can be summarized as follows:-

The average effective field capacity and field efficiency of the reaper was found to be $0.182 \mathrm{ha} / \mathrm{h}$ and $81 \%$ respectively whereas the effective field capacity in manual harvesting was $0.008 \mathrm{ha} / \mathrm{h}$. Fuel consumption of the reaper was $0.92 \mathrm{lit} / \mathrm{h}, 5.08 \mathrm{lit} / \mathrm{ha}$. Average value of harvest losses in mechanical harvesting was 1.42 percent only whereas average value of harvesting losses in manual harvesting was $1.73 \%$ which is more than that of mechanical harvesting.

The cost of harvesting for reaper harvester and for manual harvesting were 479Birr/ha and 1600Birr/ha respectively. The percent saving in the cost of harvesting is reduced by $30 \%$ harvesting of wheat with reaper harvester over manual harvesting. For economic justification of machine application, the yearly capacity of machine must not be less than 6ha/year. It can be conclude that, the use of harvesting is much more economic and efficient for harvesting of wheat compared to manual harvesting method. Therefore in fields where the use of walking behind harvester is possible, it will play an important role in reducing production costs.

\section{REFERENCES}

Alizadeh, M. R. and A. Allameh. 2013. Evaluating rice losses in various harvesting practices. International Research Journal of Applied and Basic Sciences 4 (4): 894-901.

Bora, G. C. and G. K. Hansen. 2007. Low Cost Mechanical Aid for Rice Harvesting. Journal of Applied Sciences 7 (23):3815-3818.

R. Jaya Prakash, B. Ashwin Kumar, G. Aravind Reddy and K.Y.S. Rami Reddy, 2015. Performance evaluation of reaper-binder in rice crop.international Journal of Agricultural Engineering 8(2)

Pradhan, S.C., R. Biswajit, D.K. Das and M. Mahapatra, 1998. Evaluation of various padd harvesting methods in Orissa. India. AMA, 20: 35-38.

Singh, L. P. K. K. Jain, V. R. Vagadia and A. H. Memon, 2008. Evaluation and Improvement in Design of Self Propelled Vertical Conveyer Reaper. Agricultural mechanization in Asia, Africa, and Latin America, 39(2).

S.S. Karahle, A. V. Gajakos, P. S. Neharkar, S. R. Kamdi and S. P. Lambe, 2015. Performance Evaluation of Self-propelled Reaper Binder. International Journal of Tropical Agriculture 33(2): 0254-8755 